\title{
DÁvid Somogyi
}

\author{
"The blacklist was a time of evil..."
}

The Blacklisting in the McCarthy Era and the Hollywood Ten

\author{
Pro\&Contra 5
}

No. 1 (2021) 25-47. 



\begin{abstract}
After World War II, the Second Red Scare planted the seeds of uncertainty and hatred throughout the U.S. Before the fall of McCarthyism, ten screenwriters from Hollywood faced prosecutions due to their past allegiances. They were all members of the Communist Party of the United States of America (CPUSA). President Harry S. Truman (1884-1972) and his associates were committed to exposing anyone with even the slightest connection to the CPUSA although the President was himself a liberal. This research sheds light on the Hollywood Ten's unfortunate fate (henceforth: Ten) while discussing its contemporary politics. The Ten refused to confess and talk during their prosecutions, which led to their careers' destruction despite their blacklisting being lifted during the sixties by individuals in the industry including Dalton Trumbo (1905-1976) and Kirk Douglas (1916-2020). In the present study, relevant historical evidence, materials, and sources were consulted. It is argued here that the Hollywood Ten story retains an enormous influence on the current U.S. political climate and proposes that the recent \#MeToo movement would have failed without the sacrifice of the Hollywood Ten.
\end{abstract}

Keywords: blacklist, Hollywood Ten, McCarthyism, \#Me'Too, The Second Red Scare

\title{
Introduction
}

The period after the Second World War was a time of uncertainty and chaos. Even though the United States had seen relative peace on the home front and did not suffer the ravages witnessed elsewhere, it still suffered significant losses. Its political and ideological values were shaken, which led to a growing fear and dread in the nation. ${ }^{1}$ This fear was encapsulated by the Second Red Scare, a phenomenon exploited by various people like Joseph McCarthy (1908-1957) during the Cold War. The fear of active Soviet spies within the U.S. gave him enormous power to dissect and strip people's civic rights and liberties. One group in particular was the Hollywood Ten, comprising ten Hollywood directors, writers, and producers deemed communist by the government. They are listed in the second part of the paper. ${ }^{2}$

According to the research, loyalty hearings were held at those trying times to cement people's allegiances to the USA. The Hollywood Ten chose not to testify during the

\footnotetext{
1 “'Take A Closer Look: America Goes to War.” The National WWII Museum. https:/ /www.nationalww2museum. org/students-teachers/student-resources/research-starters/america-goes-war-take-closer-look

2 “Hollywood Ten.” Encyclopedia Britannica. https://www.britannica.com/topic/Hollywood-Ten.
} 
hearings, which lead to the end of their careers. Most of them spent six to twelve months in confinement after the prosecutions. They also spent some time in prison, away from their loved ones and families. ${ }^{3}$

Why did the Ten fight the government? Dalton Trumbo (1905-1976) was the most famous of them, even managing to continue his moviemaking career to some extent after the Hollywood Blacklist. He is known for screenplays including Roman Holiday (1953), Spartacus (1960), directed by Stanley Kubrick (July 26, 1928 - March 07, 1999), and Exodus (1960), directed by Otto Preminger (1905-1986), The Fixer (1968), Johnny Got His Gun (1971 also director), and Papillon (1973). Trumbo was among the Hollywood Ten and refused to testify before the House of Un-American Activities Committee (HUAC) in 1947 during the Committee's investigation of Communist influences in Hollywood. During this time, some of his screenplays were named after other filmmakers and he wrote others under various pseudonyms. However, in many cases, his films were shown without mentioning the screenwriter. He also visited Hungary in connection with Bernard Malamud's novel, The Fixer (1968, directed by John Frankenheimer), shot in Budapest's Mafilm studio, and stayed for four months in Hungary. ${ }^{4}$ He and his fellow prosecuted men were part of the Communist Party of the United States when it was acceptable to be a part of such groups. As he argued in his loyalty hearing: "I do not belong to any organization whose conduct is intentionally destructive of them inimical to the government of the United States..." ${ }^{5}$ When the Second Red Scare enveloped America, they suffered and fought against McCarthyism and their ensuing blacklisting. McCarthyism was a blanket term for unfounded accusations against people regarding loyalty to the country mainly related to communism. ${ }^{6}$ Trumbo also followed international affairs, and in private, he criticized some aspects of Soviet behavior; however, he never wrote anti-Soviet articles. In personal correspondence, he was asked whether he ever planned to write a book about the crimes of the Stalin regime, Trumbo replied: "It is entirely conceivable that I would ... do so," adding that he had protested the imprisonment of writers opposed to the Soviet invasion of Hungary (1956), the resumption of nuclear testing (1961), and the prosecution and sentencing of dissident Soviet writers (Daniel and Sinyavsky,1966). ${ }^{7}$

The prevailing atmosphere in the USA created a hostile environment for those looking to settle there and continued to do so until the fall of McCarthyism. For decades, people

\footnotetext{
3 "Hollywood Ten."

${ }^{4}$ Larry Ceplair and Christopher Trumbo, Dalton Trumbo: Blacklisted Hollywood Radical (Lexington, KY: UP of Kentucky, 2010), 464.

5 “Dalton Trumbo, HUAC Hearings." Wisconsin Center for Film \& Theater Research. https:/ / wcftr.commarts.wisc. edu/exhibits/dalton-trumbo-papers/huac-hearings

6 "The Hollywood Ten."

${ }^{7}$ Ceplair and Trumbo, Dalton Trumbo, 474.
}

Pro\&Contra 1 (2021) 25-47. 
lived in fear of a nuclear war while enlightened individuals like the Hollywood Ten suffered their unfortunate fate. Along with the American people, institutions also lost their civil rights and had to protect themselves from the prosecutions' prying eyes. As Geoffrey R. Stone, a contemporary professor of the law, argued, "Even passing over the unfairness to those discharged or denied employment, the program's impact was devastating."

Loyalty hearings destroyed trust in the government. McCarthyism was a short-sighted idea that only benefited those willing to sacrifice others (Durr 304). How then did Joseph McCarthy rise to power? How did the Hollywood Ten deal with the blacklisting? What can we learn as a society from their fall? The three parts of this paper will scrutinize these questions. Since the Hollywood Ten story is still one of U.S. History's blind spots and in the shadow of the current \#Me'Too movement in Hollywood, I feel it is essential to raise awareness of this era and its history. To achieve the goals mentioned above, the transcripts of Dalton Trumbo's loyalty hearings are utilized. These written materials can be associated with the Ten, like Trumbo's 1939 anti-war novel Johnny Got His Gun. The 1950 John Berry documentary on the group is used as a primary source.

\section{The Second Red Scare}

It is true that currently, in the twenty-first century, we are blessed with a relatively nonhostile environment. However, tensions are rising all over the globe due to international politics and the coronavirus. The era analyzed in this paper are not dissimilar to the current climate. The Second Red Scare and the McCarthy era resulted from the Second World War. ${ }^{9}$

Based on the sources, after the Second World War, international relations were destabilized and fragile. The government of the United States were on high alert defending their state secrets from foreign spies and terrorists. We need to understand the background of public fear in those times in the U.S. before going any further. In the November of 1959, the United States Armed Forces introduced the DEFCON (Defense Readiness Condition) alert state to monitor foreign nuclear activity. This system has five readiness levels, ranging from a non-increased, usual readiness level to maximum readiness with implications of a nuclear war. The defense system was on level two for most of the Cold War. The state

\footnotetext{
${ }^{8}$ Geoffrey R. Stone, "Free Speech in the Age of McCarthy: A Cautionary Tale," California Law Review 93, no. 5 (2005): 1393.

9 “"Take A Closer Look: America Goes to War."
} 
increased its security measures and had multiple defense protocols monitoring intelligence and critical establishments. This defense classification was a form of reassurance for the American people during the Cold War. ${ }^{10}$

Espionage was not unheard of even in the USA; the Central Intelligence Agency (CIA), formed in September 1947, acts as an intelligence-gathering institution. It was the American equivalent of the KGB (Committee for State Security). However, the CIA primarily operated on foreign soil while the KGB dealt with the internal problems of the Soviet Union. They initiated multiple operations in the Cold War, gathering anything they could on Soviet troopers, movements, and their influence on other nations, such as Cuba and Guatemala. The information the CIA came acquired was highly classified; not even different branches of the U.S. government had access to it due to security reasons. Covert Operations carried out by the CIA relied heavily on public covers, political immunities, and fictional organizations for them to be as efficient as possible while gathering intelligence. These facts are essential for this paper because the fruits of espionage assisted McCarthyism create the illusion that the Soviet Union was relentlessly trying to infiltrate American soil. ${ }^{11}$

The Communist Party of the United States (CPUSA) welcomed people into their ranks when established in 1919. The people of the USA did not necessarily support the Soviets; they instead saw communism as an alternate idea for freedom and prosperity. After the Great Depression, some desired more than a return to capitalism and the rat race. The CPUSA was against fascism and initiated multiple programs for those looking for jobs and housing after the Great Depression. Since the USA and the Soviet Union were allies during the Second World War, the Communist Party had no conflict with the government and authorities. ${ }^{12}$ Things began to change after the war when the two superpowers came to loggerheads. The CPUSA was vilified, and most of its members cut ties when the Second Red Scare erupted during the Cold War. ${ }^{13}$

According to the sources, the United States had good reason for closely monitoring foreign activity, as they had multiple breaches in security during the war by Soviet spies. It is understandable why they chose to enforce such strict measures, although their fight for global surveillance over their country led to the loss of many people's civic rights. As mentioned before, the KGB was a spying network established in 1954 and was in operation until 1991, when the Soviet Union disbanded due to internal conflicts. Jacob Golos (1889-1943), a

\footnotetext{
${ }^{10}$ Joe Wallace, "DEFCON Levels," Military Benefits. https://militarybenefits.info/defcon-levels/ 11 "The CIA".

${ }^{12}$ Stone, "Free Speech," 1390.

${ }^{13}$ Victor G. Devinatz, “Communist Party of the United States of America,” Encyclopedia Britannica. https:// www.britannica.com/topic/Communist-Party-of-the-United-States-of-America
} 
Bolshevik operative, oversaw a spy ring within the USA. It is worth mentioning that he was also a founding member of the Communist Party of the United States of America. ${ }^{14}$ Upon discovering these activities after the War, President Harry S. Truman issued Executive Order 9835, the Loyalty Order. It required all federal workers to be analyzed to determine if they were loyal to the state or not. It is worth mentioning that all spies were CPUSA members, but not vice versa. People had to adapt to these changes in their work environment quickly. ${ }^{15}$ A comment from a contemporary lawyer Clifford J. Durr stated:

I am convinced that the Order's evils far outweigh any possible good that can come from it. Such potentialities of injustice, oppression, and cruelty within its administration will inevitably result in alienation rather than promoting government employees' loyalty. ${ }^{16}$

This quotation is important because the Loyalty Order cemented McCarthyism in public. Based on the research, civil rights and personal freedom were ignored alongside the First Amendment, a founding stone of the United States Constitution. The First Amendment will be discussed in greater detail when I write about Joseph McCarthy. ${ }^{17}$ As written in the Executive Order on the Truman Library's official website:

1. There shall be a loyalty investigation of every person entering the civilian employment of any department or agency of the Federal Government's executive branch.

a. Investigations of persons entering the competitive service shall be conducted by the Civil Service Commission, except in such cases as are covered by a special agreement between the Commission and any given department or agency.

b. Investigations of persons other than those entering the competitive service shall be conducted by the employing department or agency. Departments and agencies without investigative organizations shall utilize the investigative facilities of the Civil Service Commission ("Executive Order No. 9835”).

The order also led the government to oversee smaller institutions and facilities, like public schools. Teachers had to go through many regulation checks and revaluations in their material to ensure there was no threat to the State. The Board of Education also had to

\footnotetext{
14 “Jacob Golos." Atomic Heritage Foundation. https:/ /www.atomicheritage.org/profile/jacob-golos

15 “Truman's Loyalty Program.” Harry S. Truman Library and Museum. https:/ /www.trumanlibrary.gov/education/ presidential-inquiries/trumans-loyalty-program

${ }^{16}$ Clifford J. Durr, "The Loyalty Order's Challenge to the Constitution," The University of Chicago Law Review 16, no. 2 (1949): 298.

17 “Truman's Loyalty Program."
} 
go through numerous investigations and fact checking. Book burnings were held regularly, and books published within the Soviet Union were banned from the public. Such events are examples of the era's unjustifiable surveillance. ${ }^{18}$

\section{The Game of McCarthy}

The infamous U.S. Senator Joseph Raymond McCarthy from Wisconsin became the face of loyalty hearings. ${ }^{19}$ He spent three years in the U.S. Senate while he intimidated his opponents and used fear against them. In essence, the Second Red Scare was a tool employed to eradicate opposing ideals and unwanted personnel out of political and public life. It is worth mentioning that McCarthy was a good friend of the Kennedy dynasty and John Fitzgerald Kennedy (1917-1963), one of the most renowned liberal presidents of the United States to this date despite McCarthy being a hard-boiled conservative himself. Even businesses and local bodies used these tactics to destroy the hope of unionization and of fair working conditions and wages for workers. One such case was the dismissal of over two hundred and fifty municipal workers in New York due to communist allegations against the freedom of speech and fundamental civil rights. Both sides on the political spectrum enabled McCarthy and his witch hunts. The Republican Party allowed McCarthy and his political representatives to continue their witch hunts. He even pressed charges against celebrities and intellectuals who disapproved of his methods. This finding will be important later in my paper when I detail a particular group of people McCarthy prosecuted. ${ }^{20}$

His rise to power began at a Women's Republican Club meeting in West Virginia at which he declared that he had a list of two hundred and five names of communist party members. The Senate did not find anything which could compromise these people. ${ }^{21}$ More and more politicians started to distance themselves from McCarthy, seeing that he only used his power to spread fear, even though they allowed him to continue his anti-communist campaign in 1953 during his second term. ${ }^{22}$

Multiple governmental bodies attempted to work against foreign spies and spying networks. The House of Un-American Activities Committee (HUAC) was formed in 1938.

\footnotetext{
${ }^{18}$ Stuart J. Foster, 'Red Alert!: The National Education Association Confronts the 'Red Scare' in American Public Schools, 1947-1954," Education and Culture 14, no. 2 (1997): 1-16.

${ }^{19}$ Patrick J. McNamara, "McCarthy, and McCarthyism," American Catholic Studies 116, no. 2 (2005): 85.

${ }^{20}$ Stone, "Free Speech," 1392.

${ }^{21}$ McNamara, "McCarthy," 85.

${ }^{22}$ Don E. Carleton, "McCarthyism Was More Than McCarthy': Documenting the Red Scare at the State and Local Level," The Midwestern Archivist 12, no. 1 (1987): 13.
} 
It was the first Committee to oversee and prosecute people in the USA. The Committee published lists featuring individuals with questionable pasts and possible communist ties. Joseph McCarthy later used this system, using his lists to differentiate who was and was not sympathetic to Communist ideology. The HUAC played a vital role for McCarthy, as it legally instituted and allowed the stripping of one's basic rights. Fortunately, the House of Un-American Committee was abolished in 1975 when it ran under the name House Committee on Internal Security. Although this institution was the precursor of McCarthy's United States Senate Committee on Government Operations, it was not directly linked with the latter. However, he appointed the anti-communist ex-director of the HUAC, J. B. Matthews (1894-1966), as staff director soon after receiving the chair at the Subcommittee of Investigations. McCarthy's Committee was established back in 1816, dealing with the operation of post offices and railroads. In 1952 it adopted the name of Committee on Government Operations to oversee the federal government. ${ }^{23}$

Joseph McCarthy's fall began in April 1954 when he started prosecuting members of the armed services. These so-called Army-McCarthy hearings in 1954 were the fallout of both parties being unable to work with each other. These hearings were publicly broadcast on live television, which was a fatal mistake for McCarthy, as his arrogance and uncharismatic endeavor made him unlikeable to the public. ${ }^{24}$ His fall began with the summoning of Army Secretary Robert Ten Broeck Stevens (1899-1983) to testify against alleged communists among the ranks of the U.S. Military. McCarthy also wished for special treatment for his friend and staffer, G. David Schine, when serving in the Army. He insisted that he must not be deployed on foreign soil to ensure his safety. The Army retaliated with documents detailing McCarthy's subpar behavior relating to the armed services.

\section{Ruined Ideals}

The final curtain for McCarthy was a series of hearings between the Army and himself, broadcast on live television from April to June in 1954. He also tried attacking a young Army lawyer with claims of Communist affiliation because the current attorney from Boston had such connections in the past when it was acceptable to be part of the Communist Party of the United States of America before the Cold War. It prompted the Army's chief counsel, Joseph N. Welch (1890-1960), to retaliate by saying:

\footnotetext{
23 "HUAC."

${ }^{24}$ McNamara, "McCarthy," 85-86.
} 
Let us not assassinate this lad further, Senator; you've done enough. Have you no sense of decency, sir, at long last? Have you left no sense of decency? ("McCarthy-Welch Exchange")

With this, Joseph McCarthy lost all credibility. People could see first-hand how obscure and illegitimate McCarthy's accusations were. His main plan was to eliminate his opponents, not protect American citizens and their civic rights. He went against the very principle the United States Constitution stood for:

Congress shall make no law respecting an establishment of religion, or prohibiting the free exercise thereof, abridging the freedom of speech, or the press or the right of the people peaceably to assemble and petition the government for a redress of grievances. (“Amendment 1")

The Senate also condemned him for his actions. They convicted him for his inappropriate behavior. He kept his post until he died in 1957. The Catholic Church abandoned anticommunist propaganda, and all of McCarthy's allegations were dropped. Over two thousand people lost their jobs and careers during his reign. McCarthyism only benefited those willing to profit from terror, ruining opposing ideals. ${ }^{25}$ The next part of the paper will discuss the Hollywood Ten, a group of aspiring screenwriters, and examine how the U.S. government, along with Joseph McCarthy, exploited them so as to reassure themselves that their communist-hunting activities were justified. ${ }^{26}$

\section{Who were the Hollywood Ten?}

As mentioned in the previous chapter, a group of aspiring producers, writers, and directors suffered greatly because of prosecutions in the McCarthy era. They were called the Hollywood Ten or the Unfriendly Ten by their detractors. The name was coined because they consisted of ten individuals working in the Hollywood movie industry. The film industry at that time had its fair share of gossip, so the media picked up the story of the Ten as soon as they could. ${ }^{27}$ Joseph McCarthy's attacks on these individuals made them

\footnotetext{
${ }^{25}$ McNamara, "McCarthy," 87.

26 "Hollywood Ten."

${ }^{27}$ Bernard F. Dick, Radical Innocence: A Critical Study of the Hollywood Ten (Lexington: University Press of Kentucky, 1989), 2.
} 
the martyrs of the Second Red Scare. They could not do anything to save themselves from the government's clinging claws. The group was formed in the October of 1947 after they refused to speak in front of the House of Un-American Activities Committee. They were only ten of the forty-one called to give evidence to the loyalty hearings. This chapter will detail their profiles and provide an account of the prosecutions. ${ }^{28}$

Samuel Badisch Ornitz (1890-1957), John Howard Lawson (1894-1977), and Herbert J. Biberman (1900-1971) were the eldest members of the Hollywood Ten; they were all screenwriters and authors. Biberman spent the least amount of time in jail, only six months in Texas, where most of the Ten were incarcerated after the prosecution. Lawson and Ornitz had to endure twelve months of confinement far from their families. They also had no further involvement in Hollywood. However, apart from Ornitz, the other two members did additional work in the movie industry, not associating with mainstream moviemaking ever again. John Howard Lawson was a co-founder of the Screen Writers Guild, which was founded in 1933. According to his record, his blacklisting was more severe than the others because of his former relation to the guild. ${ }^{29}$

According to various sources, the other Hollywood Ten members were the author, Alvah Bessie (1904-1985). He lived the most colorful life of the group. He served as a soldier in the Spanish Civil War, wrote for Warner Brothers, and worked at a nightclub for years as a sound manager after the blacklisting. Then there was the playwright with Polish roots, Lester Cole (1904-1985). He was a teacher of screenwriting when he moved to San Francisco after staying a few years in England in the sixties. He knew his target audience very well, so he worked primarily on mass-produced films. ${ }^{30}$ The famous producer Robert Adrian Scott (1911-1972) started his journalism career and even returned to Hollywood after the sixties, working for Universal Pictures. Albert Maltz (1908-1985) began working as a playwright in New York before coming to Los Angeles and suffering a familiar fate. His career post-blacklisting was also not as successful as before, although he managed to get credit as a producer for the movie, Two Mules for Sister Sara in 1970.31

In my opinion, an unusual case, Edward Dmytryk (1908-1999), born to Ukrainian parents, had a most difficult childhood. His father did not have a stable job, and Dmytryk had to leave his home and start supporting himself from the age of fourteen. He was the only member of the Hollywood Ten who went back to the House of Un-American Activities

\footnotetext{
${ }^{28}$ David L. Dunbar, "The Hollywood Ten: The Men Who Refused to Name Names," The Hollywood Reporter, November 16, 2015, https://www.hollywoodreporter.com/lists/hollywood-ten-men-who-refused-839762

${ }^{29}$ Dunbar, "The Hollywood Ten."

${ }^{30}$ Dick, "Radical Innocence," 30.

${ }^{31}$ Dunbar, "The Hollywood Ten."
} 
Committee and testify in front of the house. He named twenty-six other ex-members of the communist party and abandoned the values the Ten appeared to uphold. He is still included in the group because initially, he was part of the movement when it formed. He went back to directing Hollywood movies after he 'cleared' his name.

Ring Lardner Jr. (1915-2000) was the youngest of the group. He was a student at the Anglo-American Institute of the University of Moscow, a fact which did not help his case when he was prosecuted. The screenwriter managed to escape the blacklist in 1965 when he was given credit for The Cincinnati Kid (1965). He was the only member of the Hollywood Ten who managed to live through the twentieth century. ${ }^{32}$

According to my findings, the most famous person out of the Ten was the screenwriter Dalton Trumbo. After his father died, he moved to Los Angeles. He started his career in writing as a side job alongside working at a bakery to help his mother and sisters and fund his studies at the University of Southern California. He wrote short stories and was a gifted student. ${ }^{33} \mathrm{He}$ began his screenwriting career when he was promoted to the story department of Warner Brothers. Apart from being an excellent screenwriter, he also managed to become a well-respected author. His book written in 1939, Johnny Got His Gun, even won a National Book Award. I mention this book because it has a strong anti-war message, which further tainted Trumbo's image for the government. It came out just two days before the Second World War broke out. A movie version of it was released in 1971, and the director was Trumbo. It was not long until the prosecutions came, and he was in prison for a year in 1950. Alongside his fellow nine artists, McCarthyism consumed his career until he was given a chance of redemption in 1960 when the renowned actor Kirk Douglas (1916-2020) helped him by giving him full name credit in the movie, Spartacus (1960) as a screenwriter. Otto Preminger (1905-1986) also did the same with Exodus (1960)..$^{34}$

\section{Tearing the Blacklist}

His resurgence with Spartacus was not as easy and straightforward as it appeared. Research on Dalton Trumbo's return to the Hollywood fold reveals exciting inconsistencies. Kirk Douglas brought Trumbo into the fold; director Eddie Lewis (1919-2019) allowed him to work on the big picture again. At first, he showed the outline for Spartacus to Trumbo,

\footnotetext{
${ }^{32}$ Dunbar, "The Hollywood Ten."

${ }^{33}$ Dick, "Radical Innocence," 184-185.

${ }^{34}$ Larry Ceplair, “Kirk Douglas, 'Spartacus,' and The Blacklist,” Cinéaste 38, no. 1 (2012): 11-13.
} 
who replaced its original writer, Howard Fast (1914-2003), without the author knowing. Trumbo started writing under the name Sam Jackson at the beginning phase of the project. At some point, Trumbo's dialogue was partly rewritten by Peter Ustinov (1921-2004), which caused him to quit the production. Kirk Douglas reported that he acted as a mediator and made a deal with Trumbo. He managed to invite him back by crediting his real name as a screenwriter when they released the movie. ${ }^{35}$

According to Eddie Lewis, Trumbo pushed for the screen credit, not Douglas in the first place. According to my research, it was ultimately Lewis who raised the idea of having Trumbo's name on the poster for Spartacus. He spoke with the heads of UniversalInternational to accept Trumbo as part of the crew. Fortunately for him, the head of the studio, Ed Muhl (1907-2001), allowed the blacklisted screenwriter to receive the screen credit for his work on the poster. Although out of precaution, he waited for the announcement just a day before the movie opened in theatres. I think it was ultimately not just Kirk Douglas who fought for Dalton Trumbo's name to be recognized again. It was a series of collaborations between the people responsible for the movie, although Kirk Douglas likes to take sole credit as written in his memoirs, The Ragman's Son (1988) and I am Spartacus: Making a Film, Breaking the Blacklist (2012).

Though Douglas continues to be hailed in Hollywood as the "man who broke the blacklist," his future reputation will not, in my estimation, be helped with this book. He is unreliable as a historian of the blacklist. ${ }^{36}$

He indeed played an important part, as he allowed Trumbo to start writing for the movie. He did make a difference, although it is an over-exaggeration to state that he alone broke the Hollywood Blacklist. ${ }^{37}$

\section{A Fight Lost Against Time}

The Hollywood Ten began its fight in the October of 1947 when they stood before the House of Un-American Activities Committee. They had all joined the Communist Party of the United States of America previously in their lives, a fact which led to their summons and the main charge against them. The HUAC inquired about this exact fact during the trials:

\footnotetext{
${ }^{35}$ Ceplair, "Kirk Douglas,” 11-13.

${ }^{36}$ Ceplair, "Kirk Douglas," 13.

${ }^{37}$ Ceplair, "Kirk Douglas," 11-13.
} 
"Are you now or have you ever been a member of the Communist Party?" The Ten bravely tried to fight back against the HUAC on the terms of the First Amendment. They believed that their freedom of speech, political identities, and the CPUSA being a non-violent group could protect them from prosecution but unfortunately, they were wrong. They were the public face of the prosecutions and public vilification. All of them were fined a thousand dollars each in addition to prison time. Alvah Bessie, during the trial, argued that "I will never aid or abet such a committee in its patent attempt to foster the sort of intimidation and terror that is the inevitable precursor of a fascist regime." 38

The Hollywood Ten became the center of the discourse about the legitimacy of the HUAC activities in Washington. They protested and spoke publicly against the court's declaration, but it was too late for them. According to the sources, after the HUAC marked them as communist sympathizers, none of the big Hollywood studios wanted to work with them again. I firmly believe that they were targeted because, as screenwriters, they were the brains behind the movies. They made all the critical decisions in the filming process, unlike the actors, for example. Even people associated with the blacklisted individuals were in danger of unemployment and shunning. ${ }^{39}$ From November 1947 through 1948, all of the Ten were sentenced to six months in federal prison.

There were two categories regarding these prosecutions: the blacklist and the gray list. People on the gray list were as vilified as the people on the blacklist. The only difference was that they could still find minor work in their fields. Just like the Ten, individuals were given an opportunity to officially denounce their communist views in front of the court, which many did so as to continue their work in their respective fields. ${ }^{40}$

I understand that the prosecutions against artists in the Hollywood movie industry were a complex procedure, an attempt to ensure a mutual relationship between institutions and media companies. The HUAC had to provide the evidence, while it was the respectable movie studio's job to expel and no longer employ the prosecuted individual. Individuals targeted by the media only had the illusion of free speech. As stated by Dalton Trumbo in an excerpt from the HUAC hearings: "The committee in its hearings has clearly and consistently attacked the constitutional guarantees of a free press..."

The studios relied on lists and updates from the hearings taking place in Washington, so they always had the latest information available so as to be able to determine whether they

\footnotetext{
${ }^{38}$ Dunbar, "The Hollywood Ten."

${ }^{39}$ Dunbar, "The Hollywood Ten."

${ }^{40}$ Elizabeth Pontikes et al., "Stained Red: A Study of Stigma by Association to Blacklisted Artists during the 'Red Scare' in Hollywood, 1945 to 1960," American Sociological Review 75, no. 3 (2010): 461.

41 "Dalton Trumbo, HUAC Hearings."
}

Pro\&Contra 1 (2021) 25-47. 
currently employed individuals on the list or not. The media was also heavily influenced by the government, and they were afraid that if they challenged the current power in favor of the Ten, they would be deemed communists. John Berry (1917-1999) was one of the few writer-directors who dared to make a short documentary on the Hollywood Ten in a film of the same name in 1950. As a result, he was also blacklisted after the movie was released. ${ }^{42}$ Berry's short movie is an essential historical source in mapping and understanding the Hollywood Ten case from their perspective. Elizabeth Pontikes highlights the atmosphere of the era in her article, arguing that:

The public supported blacklisting: for example, supermarket owners threatened to boycott films that featured communists. Laurence Johnson, a supermarket owner in Syracuse, New York, threatened to place signs in his stores warning customers not to buy products of any company that sponsored a program starring one of "Stalin's little creatures". ${ }^{43}$

The fight against blacklisting only became a justifiable cause after the sixties, when McCarthy and the Second Red Scare faded from public consciousness. Although their careers were ruined, their fight became the standing stone of the repressed of those times, and they had an enormous influence on generations to come. ${ }^{44}$

\section{The American Legion: Foes or Allies?}

Unfortunately, the Ten's cruel fate was not a wake-up call to those prosecuting innocent individuals and groups around the U.S. More victims followed for years to come until McCarthy's eventual fall. As mentioned in the first chapter, various groups wholeheartedly supported the blacklisting and McCarthy. One such organization was the American Legion, which boycotted the Hollywood Ten's works and remained convinced of McCarthy's prosecutions. This non-profit group was founded on March 15, 1919, by war veterans from the First World War. The founding members included the son of the president of the same name, Lt. Col. Theodore Roosevelt, Jr. (1887-1944), an officer of the National Guard, George A. White (1880-1941), and an ex-congressman, Ralph D. Cole (1873-1932).

\footnotetext{
${ }^{42}$ Pontikes et al., "Stained Red," 461.

${ }^{43}$ Pontikes et al., "Stained Red," 461.

${ }^{44}$ Pontikes et al., "Stained Red," 462.
} 
They played a decisive role in forming the American society of the era. The romanticizing of militarism in the USA soared with this group's foundation. ${ }^{45}$

According to the research, this non-profit group's aim was, at least not initially, witchhunting and boycotting individuals due to the fear of communism but aiding sick and war veterans. They advocated scholarship and real estate for returning soldiers all around the United States of America. The famous GI Bill of Rights in 1944 was heavily promoted by them, enabling cheap housing and funds for the education for millions of soldiers returning from the war. Like many other militaristic groups in the U.S., they also endorsed numerous sports teams and Boy Scout Organizations helping American youth assimilate into society. This group rapidly grew in numbers and profited from contributions. They currently have nearly two million members across the U.S. taking part in organized events and lobbying for army personnel and war veterans, with National Commander James W. Oxford, elected in 2019. ${ }^{46}$

This group seemingly had noble ideals until the Second Red Scare, when Joseph McCarthy gained the spotlight due to his anti-communist propaganda. The American Legion chose to endorse McCarthy primarily because of his patriotic ideals, which were, in the author's opinion, esteemed by war veterans returning home after fighting for their country. They began to make demands in political life, aiming to end the Korean War at all costs and rooting out various personnel, like Secretary of the State Dean Acheson (1893-1971) from their posts. The Legion started boycotting media from individuals with associations with the Communist Party of the United States. ${ }^{47}$

One particular film relevant to this research is Edward Dmytryk's Give Us This Day (1949) ${ }^{48}$ which the American Legion shunned. The Legion warned theatres that it would boycott them unless they removed the movie from their establishments. ${ }^{49}$ As we now know, Dmytryk cleared his name by editing his statement about his CPUSA background a few years after his blacklisting; others were not so lucky. The American Legion promoted all manner of regulations in an attempt to undermine personal freedom and civil rights. They aided the identification of suspected communists and lobbied for all previous CPUSA members to be prosecuted under the charge of treason. They also provided lists and media campaigns. The Hollywood Ten was just one group of people whom the Legion targeted. Their aims of purifying the government from the communist threat died with

\footnotetext{
${ }^{45}$ Marquis James, A History of the American Legion (New York: William Green, 1923), 15-16.

46 "About the National Commander."

47 "Red Scare Dominates American Politics."

${ }^{48}$ Give Us This Day (1949).

${ }^{49}$ Sue Harper and Vincent Porter, British Cinema of the 1950s: The Decline of Deference (Oxford University Press, 2003$), 15$.
} 
the fall of Joseph McCarthy. Their Americanism continued to play an essential part in the organization's system, although fortunately, their witch hunts and boycotts stopped after a period of time. ${ }^{50}$

\section{The Past Versus the Present}

In my opinion, the American Legion's dark history is reflected in our current political climate and culture in the USA. Would organizations like the Legion boycott media like they used to if there were to be another Red Scare or a similar phenomenon nowadays? After the 1960s, the Unfriendly Ten became the Hollywood Ten and ceased to be demonized and shunned by the movie industry. ${ }^{51}$ The political climate is an ever-changing field, as written by Arthur Eckstein, a professor of history at the University of Maryland:

On October 27, 1997, on the fiftieth anniversary of the original HUAC hearings, there was a gala celebration of the Ten, with a massive audience of the Hollywood creative elite, and with significant stars appearing as members of the Ten in a re-enactment of parts of the HUAC. ${ }^{52}$

Their careers were irreversibly damaged, although, as mentioned before, they still managed to work in the industry in various capacities. It is contended here that a few potentially wonderful careers and works coming from members of the Hollywood Ten were lost due to their blacklisting. Who knows how different the current Hollywood climate would be had it not been for the Second Red Scare?

The most recent inquisition in Hollywood, the \#MeToo movement, does, at least on a surface level, invoke memories of the Hollywood Ten and their persecution. However, \#MeToo, fortunately, has had a positive effect on the industry, unlike the events of the Second Red Scare. It is a fact that these types of movement always carry a heavy burden. If the wrong people get prosecuted or labelled as something they are not, in our case, ten aspiring screenwriters, it is hard to come back from such accusations. One sensational magazine headline can ruin one's career if one gets on the wrong side of the media. I believe that we have positively progressed as a society since the fifties. Therefore, oppressed

\footnotetext{
${ }^{50}$ M. J. Heale, American Anticommunism: Combating the Enemy Within 1830-1970 (Baltimore \& London: Johns Hopkins University Press, 1990), 173, 187; Don E. Carleton, Red Scare: Right-Wing Hysteria, Fifties Fanaticism and their Legacy in Texas (University of Texas Press, 2014), 357.

${ }^{51}$ Arthur Eckstein, "The Hollywood Ten in History and Memory," Film History 16, no. 4 (2004): 424.

${ }^{52}$ Eckstein, "The Hollywood Ten," 425.
} 
individuals working in the movie industry could rise and stand against Harvey Weinstein. They were more fortunate than the Hollywood Ten in the sense that they had a much more comprehensive platform to voice their opinions from. If the Ten had the power of the Internet, which was ironically an invention of the Cold War back in the fifties, they would have had a better chance at breaking the stereotypes and unfair accusations of those espousing Joseph McCarthy's ideals. ${ }^{53}$

\section{Our Future, Our Fight}

Good public relations have become one of the most critical aspects of the movie and media industry of late. The Ten's public stunt against the government was such a controversial event that a similar movement would get conflicting reactions from two opposing sides. With today's technology of photo editing and deepfakes, which is used to edit one's dialogue and expressions in a video, we would have difficulty decrypting what is fake and not. Ultimately, it is a gamble to take a stand against oppressing forces in any industry. We can celebrate that the \#MeToo movement managed to expose individuals in Hollywood, exploiting their power to engage in sexual violence, rape, and blackmail. ${ }^{54}$

As Eckstein argues:

because of the cultural shift in Hollywood to domination by a bien-pensant Left that started around 1960 and accelerated in the 1970s, the Unfriendly Ten are now lionized as American 'rebels' and martyred 'non-conformists'. ${ }^{55}$

The case of the Hollywood Ten has become a symbol of retaliation against oppressing forces and ideals. McCarthyism and the Second Red Scare might have ended their careers, but they could not extinguish the flame of their spirits. We do not know when the next big scandal in the Hollywood movie industry breaks out. We only know that we have people we can take an example from. The internet gives us another weapon for fight injustice. Governments and regimes can no longer hide their questionable means of stripping people of their civic rights. We can find and judge every major event occurring in our world with the push of a button or the touch of a screen. We have to distinguish blatant propaganda from actual policies

\footnotetext{
${ }^{53}$ Moira Donegan, "Harvey Weinstein went from untouchable to incarcerated. Thank \#MeToo," The Guardian. https://www.theguardian.com/commentisfree/2020/feb/24/harvey-weinstein-untouchable-guilty-thank-me-too ${ }^{54}$ Donegan, "Harvey Weinstein."

${ }^{55}$ Eckstein, “The Hollywood Ten,” 425.
} 
because nothing is black and white in our world. The internet can also be used for clearing someone's name, not just for giving labels. In the past, there was less information available to create judgments about accused individuals. Now we can surf the internet and research to create our narratives. The \#MeToo movement and the Hollywood Ten case demonstrates that we should not take oppression lightly. If questionable behavior is accepted, the bubble of sorrow and pain will burst and expose the individuals responsible for the wrongdoings.

The Hollywood Ten were victims of their trying times like some people are victims nowadays. The government, the laypeople, and the media have to learn to make careful deductions while investigating someone and their background. The Cold War primarily featured proxy wars, yet still had its victims just like any other war in history. Political correctness originates from the contemporary politics of a specific age, and therefore the Ten were 'canceled', as it might be termed today. It was not politically correct to have communist backgrounds, no matter how much they pursued those ideals. Politics changes over time, and I hope that the American and every society worldwide can progress past discriminating against individuals based on their abandoned ideals in their pasts. Sacrificing its people's rights and ignoring the amendments that the country was built upon was a grave mistake, in my opinion. While trying to defend our own, we should not make humanity as divided as in the fifties. The human species is prone to revolution and always retaliates when cornered with false narratives and ideals.

\section{Conclusion}

In the end, the Second Red Scare and the Hollywood Ten case were a history lesson learned the hard way. Some people lost the government's respect and their peers, such as Dalton Trumbo or Alvah Bessie. In contrast, some people and groups like Joseph McCarthy and the American Legion profited from the population's fear. The Ten showed us that no matter how desperate our situation is, we can always make sure that history remembers our cause. If they were to accept their fates silently while doing nothing in retaliation, we would not celebrate them as free speech heroes in our current era. In my opinion, fighting against all the odds for justice is the most heroic act one can undertake. The Cold War made the government of the United States of America commit acts of terror. It does not reflect well in retrospect but demonstrates that we have to look back at history and see what went wrong to progress as a society in the twenty-first century.

This paper has demonstrated that it is essential the issues of the past be discussed even if they are controversial. Free speech and activism are as important as ever, as evidenced 
by the current world climate. Society may indeed have other fights in the future for justice, like the \#MeToo movement. Humans have the right to expand and cherish their freedom and dreams, although it often leads to conflict with people essentially wishing the same for themselves. I end my research with Trumbo's words delivering a final judgment on the era: "The blacklist was a time of evil (...) there were only victims" (Dalton Trumbo).

\section{References}

"American Legion." Encyclopedia Britannica. https://www.britannica.com/topic/AmericanLegion.

“Hollywood Ten.” Encyclopedia Britannica. https:/ / www.britannica.com/topic/Hollywood-Ten.

"About the National Commander." The American Legion. https: / www.legion.org/commander/ bio

"Dalton Trumbo, HUAC Hearings." Wisconsin Center for Film \& Theater Research. https:// wcftr.commarts.wisc.edu/exhibits/dalton-trumbo-papers/huac-hearings

"McCarthy-Welch Exchange." American Rhetoric. https://www.americanrhetoric.com/ speeches/welch-mccarthy.html.

"Red Scare dominates American politics." HISTORY. https:/ /www.history.com/this-dayin-history/red-scare-dominates-american-politics

“Executive Order 9835.” Harry S. Truman Library and Museum. https:/ / www.trumanlibrary. gov/library/executive-orders/9835/executive-order-9835

"First Amendment." Legal Information Institute. Cornell Law School. https:/ /www.law.cornell. edu/constitution/first_amendment

“HUAC." History A\&E Television Networks. October 29, 2009. https:/ /www.history.com/ topics/cold-war/huac

"Jacob Golos." Atomic Heritage Foundation. https:/ / www.atomicheritage.org/profile/jacobgolos 
“Take A Closer Look: America Goes to War." The National WWII Museum. https://www. nationalww2museum.org/students-teachers/student-resources/research-starters/americagoes-war-take-closer-look

"The CIA." Central Intelligence Agency. United States government. Central Intelligence Agency. https:// www.cia.gov/legacy/cia-history/

“Truman's Loyalty Program.” Harry S. Truman Library and Museum. https:/ / www.trumanlibrary. gov/education/presidential-inquiries/trumans-loyalty-program

Berry, John, director. The Hollywood Ten (1950), The Criterion Collection, 1950, www.youtube. $\mathrm{com} /$ watch? $\mathrm{v}=$ taancRcLQ8o.

Ceplair, Larry and Christopher Trumbo. Dalton Trumbo: Blacklisted Hollywood Radical. Lexington, KY: UP of Kentucky, 2010.

Ceplair, Larry. “Kirk Douglas, 'Spartacus,' and The Blacklist.” Cinéaste 38, no. 1 (2012): 11-13. www.jstor.org/stable/43500988

Carleton, Don E. Red Scare: Right-Wing Hysteria, Fifties Fanaticism and their Legacy in Texas. University of Texas Press, 2014. https:// doi.org/10.7560/758551

Carleton, Don E. "'McCarthyism Was More Than McCarthy': Documenting the Red Scare at the State and Local Level." The Midwestern Archivist 12, no. 1 (1987): 13-19. www.jstor. org/stable/41101686

Devinatz, Victor G. "Communist Party of the United States of America." Encyclopedia Britannica. https:/ /www.britannica.com/topic/Communist-Party-of-the-United-Statesof-America

Dick, Bernard F. Radical Innocence: A Critical Study of the Hollywood Ten. Lexington: University Press of Kentucky, 1989.

Donegan, Moira. "Harvey Weinstein went from untouchable to incarcerated. Thank \#Me'Too." The Guardian. https://www.theguardian.com/commentisfree/2020/feb/24/ harvey-weinstein-untouchable-guilty-thank-me-too 
Dunbar, David L. "The Hollywood Ten: The Men Who Refused to Name Names." The Hollywood Reporter. November 16, 2015. https://www.hollywoodreporter.com/lists/ hollywood-ten-men-who-refused-839762

Durr, Clifford J. "The Loyalty Order's Challenge to the Constitution." The University of Chicago Law Review 16, no. 2 (1949): 298-306. https:/ / doi.org/10.2307/1597952

Eckstein, Arthur. "The Hollywood Ten in History and Memory." Film History 16, no. 4 (2004): 424-436. https://doi.org/10.2979/FIL.2004.16.4.424

Foster, Stuart J. "Red Alert!: The National Education Association Confronts the 'Red Scare' in American Public Schools, 1947-1954.” Education and Culture 14, no. 2 (1997): 1-16. www. jstor.org/stable/42922425.

Harper, Sue and Vincent Porter. British Cinema of the 1950s: The Decline of Deference. Oxford University Press, 2003.

Heale, M. J., American Anticommunism: Combating the Enemy Within 1830-1970. Baltimore \& London: Johns Hopkins University Press, 1990.

Hudson, Miles. "Why did Joseph McCarthy's influence decline?" Encyclopedia Britannica. https://www.britannica.com/story/why-did-joseph-mccarthys-influence-decline

James, Marquis. A History of the American Legion. New York: William Green, 1923.

McNamara, Patrick J. "McCarthy, and McCarthyism." American Catholic Studies 116, no. 2 (2005): 85-88. www.jstor.org/stable/44194883

Pontikes, Elizabeth, et al. "Stained Red: A Study of Stigma by Association to Blacklisted Artists during the 'Red Scare' in Hollywood, 1945 to 1960." American Sociological Review 75, no. 3 (2010): 456-478. https://doi.org/10.1177/0003122410368929

Schickel, Richard. "Return of the Hollywood Ten." Film Comment 17, no. 2 (1981): 11-17. www.jstor.org/stable/43451345

Stone, Geoffrey R. "Free Speech in the Age of McCarthy: A Cautionary Tale." California Law Review 93, no. 5 (2005): 1387-1412. www.jstor.org/stable/30038489 
The Editors of IMDb. "Give Us This Day (1949)." Internet Movie Database. https://www. imdb.com/title/tt0041416/

Wallace, Joe. “DEFCON Levels.” Military Benefits. https:// militarybenefits.info/defcon-levels/ 